\title{
Attitudes towards forest and wildlife, and conservation-oriented traditions, around Chakrashila Wildlife Sanctuary, Assam, India
}

\author{
Simi Talukdar and Abhik Gupta
}

\begin{abstract}
We examined attitudes towards forest and wildlife among Rabha, Bodo and Rajbongshi communities from three villages in the Chakrashila Wildlife Sanctuary of western Assam, India. The study was conducted through openended and structured interviews, focus group discussions, and participatory rural appraisal. The respondents identified availability of forest products, biodiversity conservation and the aesthetic beauty of the forest as the major justifications for the establishment of Chakrashila as a protected area. They also believed that people and wildlife could coexist peacefully, although some respondents did not have a cordial relationship with Forest Department staff. Most respondents were favourably disposed towards the golden langur Trachypithecus geei because it did not harm anybody or damage crops, and because of its shining coat and its exalted status in their religious beliefs. They were antagonistic towards the rhesus macaque Macaca mulatta because of its crop-raiding habits, although they were averse to killing it. Most respondents did not want to relocate because they lacked skills and resources and had associations with the forest, where they maintained sacred groves and observed taboos on hunting and plant resource extraction. Thus, the attitudes of the communities were governed not only by their material needs and priorities but also by their deep-rooted cultural-religious bond with the forest. These matters would benefit from being incorporated into forest management strategies in developing countries.
\end{abstract}

Keywords Assam, Bodo, Bodoland Territorial Area District, community attitudes, Rabha, Rajbongshi, sacred grove, taboo

\section{Introduction}

orests and forest people in India have a chequered his- tory. With the advent of colonial rule, the traditional, largely community-based systems of forest management were replaced by more stringent government control over forests. Consequently, forest dwellers were deprived of their traditional rights to forest resources (Naughton-

Simi TAluKDar and ABHIK GUPTA (Corresponding author) Department of Ecology and Environmental Science, Assam University, Silchar, Assam 788011, India. E-mail abhik.eco@gmail.com

Received 23 May 2016. Revision requested 28 June 2016.

Accepted 18 October 2016. First published online 9 March 2017.
Treves et al., 2005). This approach continued to be perpetuated in the post-independence period until revision of the forest policy in 1988 advocated a participatory approach towards forest management, with protected areas playing a role in sustaining people's livelihoods, biodiversity conservation, poverty alleviation and cultural practices (McNeely, 1995; Ghimire \& Pimbert, 1997). Furthermore, the Scheduled Tribes and Other Traditional Forest Dwellers Recognition Act, 2006, provided formal approval of the rights of scheduled tribes (indigenous peoples who are officially recognized in India as being socially disadvantaged) and other forest dwellers (c. $8 \%$ of India's population) over the country's forest resources (Rangarajan, 2005). In such an approach it is essential to understand the attitudes and perceptions of indigenous communities living on the fringes of protected areas (Osmond, 1994; Brandon, 2000) and to garner their support for protection (McNeely \& Miller, 1994). Factors that promote positive or negative attitudes towards conservation also need to be understood, as benefits gained from the forest are known to lead to positive attitudes, whereas costs associated with conservation, such as crop-raiding and depredation of livestock by wildlife, generate negative attitudes (Heinen, 1993; Fiallo \& Jacobson, 1995; de Boer \& Baquete, 1998; Udaya Sekhar, 1998; Gillingham \& Lee, 1999; Hamilton et al., 2000; Abbot et al., 2001; Mehta \& Heinen, 2001; Walpole \& Goodwin, 2001). As attitudes play a crucial role in the acceptance or rejection of environmental policies and management actions (Winter et al., 2005), it is important to examine them before formulating policies and management actions or generating public awareness (Gillingham \& Lee, 1999; Soto et al., 2001; Kaltenborn et al., 2006). Attitudes may in turn be influenced by level of education, work environment, age, and a host of other factors (Karanth et al., 2008).

In developing countries, communities living in or near forest not only extract resources from forests but also promote conservation through their customary laws, religious beliefs and cultural practices (Berkes et al., 2000; Lingard et al., 2003; Berkes, 2004; Peterson et al., 2007; Sasaki et al., 2010). Sacred groves are a good example of the links between the cultural practices of ethnic people and forest conservation (Khiewtam \& Ramakrishnan, 1989; Deb et al., 1997; Gupta \& Guha, 2002; Bhakat \& Pandit, 2003; Khan et al., 2008; Ngara \& Mangizvo, 2013). Besides sacred groves, many societies observe taboos around hunting, 
fishing and food, which ensure prudent extraction of resources (Singh et al., 2003; Patnaik, 2007; Meyer-Rochow, 2009; Jimoh et al., 2012; Gupta et al., 2016). These practices in turn influence social behaviour with regard to nature (Saj et al., 2006). Nonetheless, there are also many examples of the detrimental effects of local communities on forest and wildlife, such as deforestation and reduced density of trees and saplings (Kinnaird et al., 2003; Nagendra et al., 2010), poaching of tigers Panthera tigris and killing or dehorning of rhinoceroses Rhinoceros unicornis (Damania et al., 2003; Martin et al., 2009). Hunting of many species is also related to cultural beliefs (Selvan et al., 2013; Velho \& Laurance, 2013; Bobo et al., 2014), yet nature worship and feelings of kinship with nature are characteristic of many indigenous communities in Assam and the other states of north-east India (Gupta \& Guha, 2002; Singh et al., 2003).

Various social taboos serve to prevent and reduce hunting, or protect specific ecosystems through prohibition or regulation of unsustainable resource extraction (Colding \& Folke, 2001). Observance of sacred grove taboos, which are often gender-specific, has contributed to biodiversity conservation in Ghana (Barre et al., 2009). Sacred groves have also served as refugia for biodiversity in several parts of India, although their importance is declining as a result of economic pressure and changing cultural, and sometimes religious, scenarios (Chandran \& Hughes, 2000; Ormsby, 2013). The density of medicinal plants in sacred groves in India was found to be almost twice as high as that in statecontrolled reserve forests, and there was less conflict in sacred groves (Boraiah et al., 2003; Anthwal et al., 2010). In Zimbabwe there is less deforestation in forests that are or were considered to be sacred, compared to those where traditional leaders and values have been disempowered; thus, incorporating cultural-religious values, beliefs and institutions into conservation programmes could be a more effective strategy than ignoring them (Byers et al., 2001).

Kokrajhar, Chirang, Baksa and Udalguri districts, which belong to the Bodoland Territorial Area Districts of Lower Assam, India, are rich in floral and faunal diversity (Paul \& Narzary, 2010). The villages on the peripheries of most forests in this area are inhabited by ethnic communities, including Bodo, Rabha, Rajbongshi, Garo and others. The area therefore offers an opportunity to study the attitudes of these communities towards forest and wildlife, and to document the traditional conservation-oriented cultural practices, which in turn are likely to influence societal attitudes towards nature and its conservation. Three tribal communities, Bodo, Rabha and Rajbongshi, living in the Chakrashila Wildlife Sanctuary, were chosen for this study. Our major objective was to examine the communities' attitudes towards forest and wildlife in their vicinity, and the role played by their material dependence on the forest, as well as their religious beliefs and cultural practices, in shaping these attitudes. Rabha and Rajbongshi communities comprise two major religious groups: Vaishnav and Shivsonaton. The former worship the god Vishnu, and the latter Shiva. Non-violence, humility and vegetarianism are integral parts of the Vaishnava faith, and members of the Shivsonaton have many places of Shiva worship in the forest. The Bodos follow Bathouism, which is a form of ancestor worship, of which worship of the siju Euphorbia ligularia Roxb. plant is an integral part (Baishya, 2001). All three religious belief systems have strong ecocentric and biophilic dimensions, which are likely to shape their adherents' attitudes towards nature. Our study was designed to yield information on the indigenous communities' material as well as religious-cultural dependence on the forest, which may be useful in garnering community support for conservation not only in this region of India but also in similar situations in other parts of the world.

\section{Study area}

The study was conducted in the Chakrashila Wildlife Sanctuary $\left(45,568 \mathrm{~km}^{2}\right)$ in the Kokrajhar and Dhubri districts of western Assam (Fig. 1). The forests of Chakrashila were zemindari forests (i.e. belonging to local landlords) in the Bijni region during the British rule, and the area was designated a reserve forest in 1966. Unchecked deforestation and hunting resulted in severe degradation, which prompted Nature's Beckon, a local NGO, to initiate various programmes for generating awareness among the local inhabitants, who participated in a movement that led to the establishment of Chakrashila Wildlife Sanctuary in 1994 (Kothari et al., 2000). The Sanctuary has a hilly terrain covered with semievergreen and moist deciduous forest interspersed with patches of grassland and scattered bushes, and represents the southernmost distribution of the Endangered golden langur Trachypithecus geei, which is endemic to western Assam and parts of Bhutan and is the Sanctuary's flagship species. Chakrashila also harbours 33 other species of mammals, 273 species of birds, 24 species of reptiles and amphibians, 60 species of fishes and 107 species of plants (Datta et al., 1998).

The study focused on three villages in the vicinity of Chakrashila Wildlife Sanctuary: Jornagra (inhabited by the Rabha community), Bandarpara (inhabited by the Bodo) and Kaljani (inhabited by the Rajbongshi). Bandarpara is located c. $1 \mathrm{~km}$ from the forested areas of the Sanctuary, Jornagra c. 3-4 km and Kaljani c. 5-6 km. The three communities grow crops such as paddy, mustard and various vegetables, and rear poultry, goats, pigs and cattle, both for self-consumption and trade.

\section{Methods}

Preliminary surveys were conducted in 2010 and were followed by collection of detailed information, including 


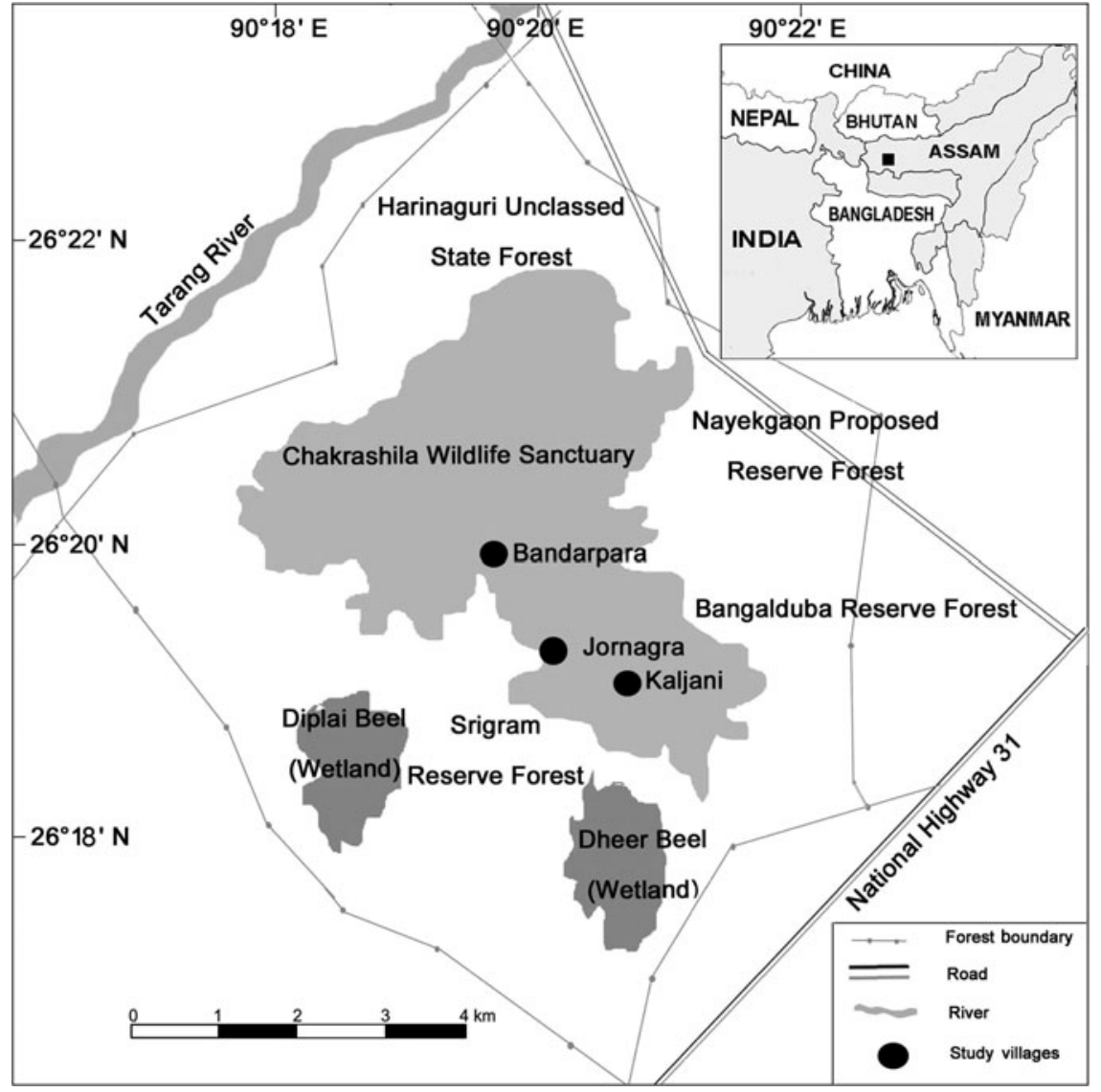

FIG. 1 Location of the study villages in Chakrashila Wildlife Sanctuary, Assam, India. about local culture and traditional customs, during 20112013, when ST lived in Jornagra. Research was conducted using a mixed-method approach (Ogra, 2009) to collect both qualitative and quantitative data. Quantitative data were collected during interviews using structured (openand closed-ended questions) and semi-structured questions (Udaya Sekhar, 2003; Ogra, 2009; Torri, 2010; Ebua et al., 2011), and qualitative data were collected through a focus group discussion and participatory rural appraisal (Bernard, 2002; Bajracharya et al., 2006; Kalibo \& Medley, 2007). The thematic coding approach was used in qualitative analysis, grouping the data into common categories or themes prior to analysis (Bernard, 2002). The participatory rural appraisal comprised informal discussions to elicit an oral history of the study sites and local people's involvement in the wildlife sanctuary movement, resource availability in the Chakrashila landscape, including the availability of wild animals and plants, resources extracted before and after the protected area was designated, and crop landraces (i.e. local varieties) cultivated. Transect surveys were conducted on foot with at least one local plant expert and one interpreter, to learn about local perspectives on the status and distribution of various forest resources. Prior informed consent was obtained from all interviewees and all participants in the focus group discussion and participatory rural appraisal. Secondary data on demography and forest-related matters, including documents and maps, were collected from the Block Development Office of Kokrajhar district and the Circle Office of Dhubri district of the Government of Assam.

Respondents were selected using stratified random sampling as well as purposive sampling methods. Fifty percent of households were selected at random from each of the three villages (Sah \& Heinen, 2001), and the head of each household (regardless of gender) was asked fixed-response (Badola, 1998) as well as open-ended questions (Shibia, 2010). Responses to questions about attitudes and perceptions were scored on a five-point Likert scale $(1=$ strongly agree; 2 =agree; 3 =neither agree nor disagree; 4 =disagree; 5 = strongly disagree; Likert, 1974). Thirty-seven, 17 and 15 respondents from Jornagra, Bandarpara and Kaljani, respectively, were interviewed. In addition, some key informants were selected by purposive sampling to participate in a focus group discussion. These included headmen, older knowledgeable residents, practitioners of traditional herbal medicine, people involved in conducting land measurements and fixing village boundaries, and frequent visitors to the forest. Interviews were conducted in Assamese, in which all the respondents were conversant, and local interpreters were present to help if an interviewee or the researcher did not properly understand a question or statement (Ogra, 2009). The names of plants and animals were also cross-checked and verified with the help of the interpreters. Quantitative 
data were analysed using SPSS 20 (IBM, Armonk, USA). Non-parametric Kruskal-Wallis and Mann-Whitney tests were used to check the significance of differences among data.

\section{Results}

Socio-economic profiles of Jornagra, Bandarpara and Kaljani villages

The respondents in Jornagra, Bandarpara and Kaljani did not differ significantly in terms of most of the socio-economic variables assessed, such as age, family size, land holding size, and crop production (Table 1). They also had similar literacy status. However, primary income (i.e. income from the main livelihood option on which a household depends) was significantly higher among respondents from Jornagra compared with those from Kaljani, although the differences between Jornagra and Bandarpara, and Bandarpara and Kaljani were not significant. In terms of secondary income (i.e. income from supplementary sources, or substitute income on which households depend during periods when the primary income source is unavailable or inadequate) there was no significant difference among the three villages. Jornagra residents grew several paddy varieties that included several landraces, whereas Bandarpara and Kaljani residents grew only one or two varieties (Table 1). Jornagra residents used split banana trunks to transport water for irrigating their paddy fields and were not entirely dependent on rainwater for agriculture. In Kaljani prolonged inundation of agricultural land by flood waters from nearby wetlands posed constraints on agriculture. Chemical fertilizers and pesticides were used mostly in Jornagra.

\section{Community attitudes and perceptions}

In Bandarpara and Jornagra the availability of forest products was identified as the highest priority for maintaining Chakrashila as a protected area ( 76.47 and $54.05 \%$, respectively), followed by biodiversity conservation (23.53 and $45.95 \%$, respectively). In Kaljani $53.33 \%$ of respondents identified biodiversity conservation as the highest priority, followed by forest products $(46.67 \%)$. Aesthetic beauty was the third most important priority in all three villages, and availability of medicinal plants was the fourth. The respondents' opinions and perceptions of conservation-related issues in the wildlife sanctuary (summarized in Table 2) reveal that c. $75-89 \%$ of the respondents from the three villages were supportive of the government's efforts to protect forest and wildlife through legislation. Circa $93-100 \%$ also believed that people and wildlife could coexist in the sanctuary area. The duration of residence was not an important factor in these villages, as almost all the respondents were born in the villages, and those who had migrated belonged to the resident community of the village, and had therefore integrated into the cultural-religious milieu. In terms of frequency of forest visits (Table 3) the percentage of respondents making weekly visits was highest in Bandarpara (88.24\%), followed by those from Jornagra (43.24\%) and Kaljani (13.33\%), reflecting the influence of proximity to the forest. Over $70 \%$ of respondents from Bandarpara and Kaljani, and $40 \%$ of those from Jornagra, did not perceive any noticeable increase in forest cover after the area was designated a protected area. Circa $30-40 \%$ of the respondents from the three communities thought that forest management was satisfactory, although $23-53 \%$ did not think so. Among the Bandarpara respondents, $64.7 \%$ did not have a cordial relationship with the forest staff; the percentages for Jornagra and Kaljani were c. 35 and $20 \%$, respectively. It is possible that the residents of Bandarpara appreciated the role of the forest staff in preventing poachers and tree-fellers but also expected to have special privileges as forest-dwellers (to be allowed to collect non-timber forest products at a subsistence level), which the forest staff did not allow. Thus the Bodo community, which lived closest to the forest, was largely unhappy with the overall management of the forest, the conflict arising mainly over access to forest products. Regarding humanwildlife conflict and related issues (Table 4), c. $58-65 \%$ of the respondents in the three villages perceived a decrease in the number of wild animals since the area was designated a wildlife sanctuary in 1994, and c. $16-26 \%$ perceived an increase. All respondents in all three villages wanted to conserve the golden langur, primarily because of its beauty and because it did not cause damage, followed by its value as a tourist attraction and its importance as the basis for the wildlife sanctuary designation. In contrast, c. $72-76 \%$ of the Jornagra and Bandarpara respondents identified the rhesus macaque Macaca mulatta as a cause of damage to paddy and fruit crops, followed by birds (21-23\%), the barking deer Muntiacus muntjak and field rats Rattus spp. (2.7\% each). In Kaljani 20 and $33.3 \%$ of the respondents disliked the rhesus macaque and birds, respectively, whereas c. $46 \%$ did not have a negative attitude towards any wildlife. Perception of crop damage was highest in Jornagra, followed by Bandarpara and Kaljani. Circa $78-86 \%$ of the respondents in the three villages identified scarcity of food and water as the primary reason for wild animals straying into human habitations. Translocation of the rhesus macaque to other areas was the most widely suggested potential measure to reduce humanwildlife conflict in Jornagra, followed by monetary compensation, whereas the reverse was the case in Bandarpara and Kaljani, although $17.7 \%$ of respondents in Bandarpara thought that deploying more forest guards would help.

\section{Taboos on resource use}

Taboos on resource use (Table 5 ) observed by the three communities were specific to their gotras (clans). The Rabha and Rajbongshi communities never consumed the species with 
TABLE 1 Socio-economic profile of study participants in Jornagra, Bandarpara and Kaljani villages in Chakrashila Wildlife Sanctuary, Assam, India (Fig. 1). Different superscripts indicate significant differences $(\mathrm{P} \leq 0.05$ : Mann-Whitney test) between values (mean $\pm \mathrm{SD})$ in a given row.

\begin{tabular}{|c|c|c|c|}
\hline \multirow[b]{2}{*}{ Variable } & \multicolumn{3}{|l|}{ Village } \\
\hline & Jornagra $(\mathrm{n}=37)$ & Bandarpara $(\mathrm{n}=17)$ & Kaljani $(\mathrm{n}=15)$ \\
\hline Age, years (range) & $44.9 \pm 13(24-70)^{\mathrm{a}}$ & $45.1 \pm 17.8(24-85)^{\mathrm{a}}$ & $57.1 \pm 14.5(28-74)^{\mathrm{a}}$ \\
\hline No. of individuals per family (range) & $4.54 \pm 1.54(2-8)^{\mathrm{a}}$ & $4.9 \pm 1.6(2-7)^{\mathrm{a}}$ & $5.2 \pm 1.7(2-8)^{\mathrm{a}}$ \\
\hline Monthly primary income, INR* (range) & $9,127.93 \pm 12,079.7(3,000-46,933.3)^{\mathrm{a}}$ & $6,443 \cdot 14 \pm 6,985.4(2,400-26,666.7)^{\mathrm{ab}}$ & $3,453.07 \pm 1,186.6(1,902-5,677)^{\mathrm{b}}$ \\
\hline Monthly secondary income, INR (range) & $1,854.95 \pm 2,207.3(2,133-8,000)^{\mathrm{a}}$ & $1,647.06 \pm 1,902.01(2,500-5,500)^{\mathrm{a}}$ & $1,300 \pm 1,672.9(3,000-4,200)^{\mathrm{a}}$ \\
\hline Land holding, ha (range) & $1.8 \pm 2.5(1.02-10.8)^{\mathrm{a}}$ & $1.61 \pm 2.6(1.02-8.13)^{\mathrm{a}}$ & $1.9 \pm 1.9(1.02-6.10)^{\mathrm{a}}$ \\
\hline Annual crop production, kg (range) & $1,169.5 \pm 1,932.1(200-7,040)^{\mathrm{a}}$ & $696.5 \pm 1,200.3(480-4,000)^{\mathrm{a}}$ & $1,008 \pm 1,271.3(240-4,200)^{\mathrm{a}}$ \\
\hline \multicolumn{4}{|l|}{ Literacy status (\%) } \\
\hline Can read and write & 51.35 & 52.9 & 46.7 \\
\hline Can sign their name & 18.9 & 11.8 & 13.3 \\
\hline Cannot read and write & 29.7 & 35.3 & 40 \\
\hline \multicolumn{4}{|l|}{ Crops cultivated (\%) } \\
\hline Sali (winter rice) & 50 & 100 & 66.7 \\
\hline Boro (summer rice) & 21.4 & 0 & 33.3 \\
\hline Ahu (autumn rice) & 7.14 & 0 & 0 \\
\hline Joha (fine-grain aromatic rice landrace) & 7.14 & 0 & 0 \\
\hline Malsira (rice landrace) & 14.3 & 0 & 0 \\
\hline
\end{tabular}

${ }^{\star} \mathrm{USD}_{1}=\mathrm{c}$. INR 66 
TABLE 2 Perceptions of conservation-related issues by respondents in Jornagra $(n=37)$, Bandarpara $(n=17)$ and Kaljani $(n=15)$ villages in Chakrashila Wildlife Sanctuary (Fig. 1), based on statements scored on a Likert scale.

\begin{tabular}{|c|c|c|c|c|c|}
\hline \multirow[b]{2}{*}{ Village } & \multicolumn{5}{|c|}{ Likert scale } \\
\hline & $\begin{array}{l}\text { Strongly } \\
\text { agree }(\%)\end{array}$ & Agree (\%) & $\begin{array}{l}\text { Neither agree } \\
\text { nor disagree }(\%)\end{array}$ & $\begin{array}{l}\text { Disagree } \\
(\%)\end{array}$ & $\begin{array}{l}\text { Strongly } \\
\text { disagree (\%) }\end{array}$ \\
\hline \multicolumn{6}{|c|}{ Wildlife should be protected through legislation } \\
\hline Jornagra & 54.05 & 35.1 & 8.11 & 2.7 & 0 \\
\hline Bandarpara & 52.94 & 23.53 & 23.53 & 0 & 0 \\
\hline Kaljani & 46.7 & 33.3 & 13.3 & 6.7 & 0 \\
\hline \multicolumn{6}{|c|}{ Wildlife and humans can coexist } \\
\hline Jornagra & 54.06 & 40.54 & 5.4 & 0 & 0 \\
\hline Bandarpara & 58.82 & 41.18 & 0 & 0 & 0 \\
\hline Kaljani & 53.33 & 40 & 6.7 & 0 & 0 \\
\hline \multicolumn{6}{|c|}{ Forest cover has increased since the designation of the Wildlife Sanctuary } \\
\hline Jornagra & 0 & 21.62 & 37.84 & 40.54 & 0 \\
\hline Bandarpara & 0 & 11.76 & 17.65 & 70.6 & 0 \\
\hline Kaljani & 0 & 6.7 & 20 & 73.3 & 0 \\
\hline \multicolumn{6}{|c|}{ Forest management is satisfactory } \\
\hline Jornagra & 8.11 & 21.6 & 21.6 & 27.03 & 21.6 \\
\hline Bandarpara & 17.65 & 23.53 & 35.29 & 17.65 & 5.9 \\
\hline Kaljani & 20 & 20 & 6.7 & 33.3 & 20 \\
\hline \multicolumn{6}{|c|}{ Relationship with the management staff of the Wildlife Sanctuary is cordial } \\
\hline Jornagra & 8.1 & 18.9 & 37.8 & 5.4 & 29.7 \\
\hline Bandarpara & 0 & 11.76 & 23.53 & 35.3 & 9.4 \\
\hline Kaljani & 6.7 & 20 & 53.33 & 6.7 & 13.3 \\
\hline
\end{tabular}

TABLE 3 Frequency of forest visits by respondents in Jornagra, Bandarpara and Kaljani villages in Chakrashila Wildlife Sanctuary (Fig. 1).

\begin{tabular}{lcll}
\hline Frequency of visit & $\begin{array}{c}\text { Jornagra, } \\
\mathrm{n}=37(\%)\end{array}$ & $\begin{array}{l}\text { Bandarpara, } \\
\mathrm{n}=17(\%)\end{array}$ & $\begin{array}{l}\text { Kaljani, } \\
\mathrm{n}=15(\%)\end{array}$ \\
\hline Weekly & 43.24 & 88.24 & 13.33 \\
Fortnightly & 8.11 & 11.76 & 0 \\
Monthly & 13.51 & 0 & 26.7 \\
Bimonthly & 8.11 & 0 & 0 \\
Six-monthly & 16.22 & 0 & 6.7 \\
Annually & 10.81 & 0 & 53.33 \\
\hline
\end{tabular}

which their gotras were identified, and also observed some restrictions on plant use. Likewise, the Bodo community followed taboos that were related to family names.

\section{Sacred groves}

Jornagra is surrounded by hills, such as Belguri, Manshikata Badha, Udalguri, Khejurguri, Haldibari, Sirakhowa, Shingimari, Bamunisura and Bagher khoj. Patches of forest on Belguri are sacred sites, and the Bamunthakur (Shiva) Temple is found at one such site. Hills near Bandarpara include Daoshinsari, Gatoibari, Antaidular, Bogasil, Badhuwa Pahar, Boglaguri Pahar, Barnangnai and Doisagaran. Deities are believed to reside in nature on Petpakhra (a local deity) and Dholashil (white rock) sacred groves, which are known locally as than. These groves cover c. 14 ha in total. There is a sacred $4-5$ ha grove near Kaljani, called Lengtiya Pahar Santijog Shivashram (Shiva temple). The dominant plant species in these groves are Terminalia bellerica, Lannea coromandelica, Shorea robusta, Cassia fistula, Toona ciliata, Bursera serrata, Aegle marmelos, Albizia procera, Terminalia chebula, Sterculia villosa, Tectona grandis, Azadirachta indica, Phyllanthus emblica, Lagerstroemia flos-reginae and Stereospermum personatum.

\section{Discussion}

The socio-economic conditions of the three communities did not differ significantly, although the primary income of the Rabhas of Jornagra was higher because of their indigenous irrigation system, which facilitated cultivation of alternative varieties of paddy, and higher productivity.

The majority (c. 75-89\%) of the respondents from the three communities supported the designation of Chakrashila as a protected area, with residents of Bandarpara being the most concerned about the availability of forest products, followed by Jornagra, probably reflecting their proximity to the forest. In contrast, more respondents from Kaljani (Rajbongshi), which is located furthest from the forest, prioritized biodiversity conservation, followed by forest products. Similarly, in Bangladesh farmers living away from the forest were found to be more supportive of conservation (Sarker \& Røskaft, 2011). However, in the Bangladesh study affluent respondents 
TABLE 4 Perceptions of human-animal conflict and related issues by respondents in Jornagra, Bandarpara and Kaljani villages in Chakrashila Wildlife Sanctuary (Fig. 1).

\begin{tabular}{|c|c|c|c|}
\hline Issues & Jornagra, $\mathrm{n}=37(\%)$ & Bandarpara, $\mathrm{n}=17(\%)$ & Kaljani, $\mathrm{n}=15(\%)$ \\
\hline \multicolumn{4}{|l|}{ Number of wild animals } \\
\hline Increased & 16.2 & 17.6 & 26.7 \\
\hline Decreased & 64.9 & 58.9 & 60 \\
\hline No change & 18.9 & 23.5 & 13.3 \\
\hline \multicolumn{4}{|c|}{ Justification for conserving the golden langur Trachypithecus geei } \\
\hline Good looks & 32.43 & 47.06 & 40 \\
\hline Never destroys anything & 37.84 & 47.06 & 40 \\
\hline Basis for designation of Wildlife Sanctuary & 16.22 & 0 & 13.3 \\
\hline Tourists come to see this animal & 13.51 & 5.88 & 6.7 \\
\hline \multicolumn{4}{|c|}{ Animal that causes most damage to paddy \& home garden fruits } \\
\hline Birds & 21.6 & 23.53 & 33.3 \\
\hline Rhesus macaque Macaca mulatta & 73 & 76.47 & 20 \\
\hline Barking deer Muntiacus muntjak & 2.7 & 0 & 0 \\
\hline Field rat Rattus spp. & 2.7 & 0 & 0 \\
\hline None & 0 & 0 & 46.7 \\
\hline \multicolumn{4}{|l|}{ Amount of crop damage by wildlife } \\
\hline No damage & 0 & 0 & 46.7 \\
\hline Negligible & 10.8 & 23.5 & 46.7 \\
\hline $25 \%$ & 27 & 5.9 & 6.7 \\
\hline $50 \%$ & 16.2 & 35.3 & 0 \\
\hline $75 \%$ & 46 & 35.3 & 0 \\
\hline \multicolumn{4}{|l|}{ Reasons for wildlife leaving the forest } \\
\hline Scarcity of food \& water & 78.4 & 82.35 & 86.7 \\
\hline Regular migration & 18.9 & 17.65 & 13.3 \\
\hline Displacement by human settlements & 0 & 0 & 0 \\
\hline Intra/interspecific competition & 2.7 & 0 & 0 \\
\hline \multicolumn{4}{|c|}{ Recommendation for minimization of conflict with $M$. mulatta } \\
\hline Killing & 0 & 0 & 0 \\
\hline Compensation for crop loss & 31.6 & 58.8 & 80 \\
\hline Translocation & 58.7 & 23.5 & 20 \\
\hline Electric fencing & 2.7 & 0 & 0 \\
\hline Deploying more forest guards & 7 & 17.7 & 0 \\
\hline
\end{tabular}

favoured conservation more than the poor, which was not observed in our study. The proximity of Bandarpara to the forest and the prioritization of forest products by its residents may also be linked to their antagonism towards forest officials, who try to restrict or regulate their entry into the forest for collection of forest products. Nevertheless, besides the importance of forests for their livelihoods, members of the three communities also attached high priority to biodiversity conservation and the aesthetic beauty of the forest. Most respondents believed that wildlife and people could coexist in this area, and although they had an antagonistic attitude towards the rhesus macaque because of its crop-raiding and other disruptive habits, they were averse to killing it. The women of Jornagra and Bandarpara were particularly antagonistic towards the rhesus macaque because when the men went to the market on Sundays and Wednesdays the women and children had to guard the crop fields, which disturbed their household chores and disrupted the children's education. The government's compensation policy covered crop damage by elephants but did not compensate for economic losses resulting from crop-raiding macaques, which was a matter of concern for the residents of Jornagra and Bandarpara. However, most respondents from Kaljani did not have negative attitudes towards any wildlife. It is known that monetary losses can make communities antagonistic and intolerant towards wildlife (Nyhus et al., 2000) and that crop fields bordering forests experience more crop raiding (Jhala, 1993; Studsrød \& Wegge, 1995; Udaya Sekhar, 1998; Hoare \& du Toit, 1999; Hill, 2000; Saj et al., 2001). In Chakrashila all three communities were favourably disposed towards the golden langur for its harmless nature and beauty. It is also sacred to the Rabha and Bodo communities, the latter believing it to be the descendant of the mythical king of monkeys, which contributes to its iconic status. This positive attitude provided a sound basis for the success of Chakrashila as a protected area. However, the forest residents also felt that they had few options, as they did not possess any land elsewhere, nor were they sufficiently skilled or educated to pursue an alternative livelihood elsewhere. Many pepole, especially the elderly, cherished their generations-old link with the forest and did not feel at home 
TABLE 5 Taboos on forest resource use by various gotras (clans) of the Rabha, Bodo and Rajbongshi communities.

\begin{tabular}{|c|c|}
\hline Gotra (clan) & Taboo \\
\hline \multicolumn{2}{|c|}{ Rabha (Jornagra village) } \\
\hline Sumri & Hunting of barking deer \& consumption of its meat \\
\hline Pamar & Hunting \& consumption of turtles \& tortoises, \& peacocks Pavo cristatus \\
\hline Kara & Hunting of barking deer \& consumption of its meat \\
\hline Sondan, Dolpha & $\begin{array}{l}\text { Use of the amla tree Phyllanthus emblica as fuel wood, \& consumption of its fruit. Anybody who touches this tree must } \\
\text { take a bath \& pray to God for forgiveness. }\end{array}$ \\
\hline Sole & Use of the bel tree Aegle marmelos as fuelwood \\
\hline Nogra & Use of cane Calamus spp. for any purpose \\
\hline Sumur & Capture \& consumption of wagtails Motacilla spp., oriental magpie robins Copsychus saularis \& barking deer \\
\hline $\begin{array}{l}\text { Majisamprai, } \\
\text { Sapra }\end{array}$ & Use of the kanchan plant Bauhinia variegata for any purpose \\
\hline Lembrai & Capture \& consumption of, or even looking at, rock pythons Python molurus \\
\hline \multicolumn{2}{|c|}{ Bodo (Bandarpara village) } \\
\hline Musahary & $\begin{array}{l}\text { Musa means tiger in the Bodo language. Whenever members of this clan hear about the death of a tiger Panthera tigris } \\
\text { they observe certain rituals in their homes. }\end{array}$ \\
\hline Basumatari & Basu means soil. Members of this clan never collect soil, sand, gravel or boulders from rivers or streams. \\
\hline \multicolumn{2}{|c|}{ Rajbongshi (Kaljani village) } \\
\hline Kashyap & $\begin{array}{l}\text { Use of pakhri Ficus benghalensis, polash Butea monosperma, bel \& am Mangifera indica trees as fuelwood is prohibited, } \\
\text { as these plants are used in religious ceremonies \& during cremation. }\end{array}$ \\
\hline
\end{tabular}

outside it. Udaya Sekhar (2003) noted that benefits obtained by local people from wildlife tourism and other related sources in the Sariska Tiger Reserve, India, were sufficient for them to ignore the losses or inconveniences suffered as a result of depredation by wildlife and restricted access to forest resources. Although wildlife tourism at Chakrashila is at a nascent stage, local people have begun to accrue some benefits after being trained by the NGO Nature's Beckon to work as cooks or guides.

As part of their cultural practices and religious beliefs the three communities maintained sacred groves that harboured several plant species valued for their timber as well as for medicinal and magico-religious purposes. Many of these plants are also protected under the clan (gotra) taboos. Informally protected areas such as sacred groves are as important as formal ones because they harbour a rich diversity of plants and animals (Bhagwat et al., 2005). Taboos are relatively more elaborate in the case of the Rabhas but are also prevalent among the other two communities. Although the area came under government protection only recently, it had been maintained in a relatively pristine condition through the traditional conservation-oriented practices of the communities. This is perhaps one of the reasons that during the focus group discussions many respondents from the communities expressed more faith in community-based conservation than in governmental initiatives to protect the Chakrashila area. This type of conservation has been shown to be effective for wildlife and plants restricted to the sacred groves of India's Western Ghats (Bhagwat et al., 2005). In the Chakrashila area a number of plants (e.g. P. emblica, A. marmelos, Calamus spp., Bauhinia variegata, Ficus benghalensis, Butea monosperma and Mangifera indica) are not used as fuelwood by specific clans, thus conserving these resources for other purposes, such as medicinal (Talukdar \& Gupta, 2014) and magico-religious use. Similar abstinence from using certain totemic plants and animals was encountered among several tribes of West Bengal (Deb \& Malhotra, 2001). Furthermore, incidences of hunting of taboo animals, such as leopards Panthera pardus, deer, pythons Python molurus, turtles (mostly Nilssonia spp. and Lissemys punctata andersoni) and certain birds, are unknown in this area. The practice of wrapping a piece of red cloth around F. benghalensis and sticking a trident into the ground under A. marmelos trees appeared to protect them from being felled, as indicated by their larger girths compared to trees found in other parts of the forest. This is similar to the protective dapo symbol placed at the entrance of forests protected under customary law in Arunachal Pradesh (Dollo et al., 2010). In a review of the role of Indian sacred groves Ormsby \& Bhagwat (2010) observed that the original deities of these groves became transformed into mainstream gods and goddesses. Transformation and absorption into the Hindu pantheon could be said to have occurred in Chakrashila also, as exemplified by the existence of several Shiva temples in the forest, and the merging of Bodo ancestor worship (obonglaoree) into Shiva worship. However, this does not appear to have diminished the zeal with which these sacred forest patches have been protected by successive generations of these communities. Thus a mutual exchange and enrichment of world views can be said to have occurred, with the nature-centric aspects of the worship of animist deities influencing Hindu religious beliefs and rendering them more environmentally benign. 
Set amidst the densely populated districts of Dhubri and Kokrajhar (1,171 and 280 people $\mathrm{km}^{-2}$, respectively), Chakrashila Wildlife Sanctuary is an island of biodiversity, $>120 \mathrm{~km}$ from the nearest biodiversity-rich area of Manas National Park. Such small reserves are negatively affected by human interference (Lindenmayer \& Franklin, 2003). The establishment of a wildlife sanctuary at Chakrashila was made possible by a popular movement involving the local people, spearheaded by the NGO Nature's Beckon. Community support, cooperation and vigilance are essential for protecting and sustaining the integrity of this sanctuary. Our findings indicate that besides ensuring the livelihood security of the local communities, it is equally necessary to take into account their cultural-religious ties with the forest, and encourage them to perpetuate these ecocentric ethical perceptions in their world views and attitudes.

However, gauging the perceptions of the communities is a challenging task, as respondents may be guarded or mask their actual views with those held by the majority of their community. The gap between the perceptions of the interviewer and interviewee is also an important factor. Despite these limitations, our findings indicate a number of trends. Firstly, the respondents from all three communities admitted that their livelihood skills did not meet the requirements for a successful urban or even a rural living away from the forest. However, their material dependence on the forest for its resources only partly explained their attitudes towards it, and especially its wildlife. For instance, even though the rhesus macaque damaged their crops and disturbed the normal rhythms of the lives of women and children, respondents were almost unanimously against killing these animals. They regarded the golden langur as a divine animal, and had totem plants and animals, which they protected in their everyday activities. Their ancestor worship is also intimately associated with the forest through the totem organisms, and various rites and rituals. Our findings show the importance of cultural-religious factors in governing the attitudes of these tribes to the forest, and any successful conservation strategy in such an area, surrounded by indigenous communities, would have to take these factors into account rather than dismissing them as less important than more resource-oriented considerations. This study emphasizes the need to address issues such as empowerment of indigenous communities, and ensure their participation in the conservation process in a more locale- or communityspecific manner. The concept of community empowerment must transcend the practice of merely providing some preconceived livelihood packages, which may not only be unsuitable or unacceptable but also lead to increasing indifference, especially among the younger generation, towards the indigenous, tradition-derived mechanisms for conserving their surroundings. The significance of cultural values in conservation has been widely recognized but these values must be integrated into conservation programmes in protected areas with indigenous communities within or close to their boundaries. Incentives for ensuring conservation ought to include support for better maintenance of sacred groves, preservation and propagation of nature-oriented folklores and other cultural elements, and strengthening of traditional institutions, instead of ignoring and disempowering them and concentrating merely on granting economic packages.

\section{Acknowledgements}

ST expresses her gratitude to the Department of Science and Technology, New Delhi, for its financial support through the INSPIRE Fellowship. We thank Dr Ananta Borah of Birjhora Mahavidyalaya for plant identification; the Forest Department of the Government of Assam; Nature's Beckon and its Director Soumyadeep Datta; Someshwar Rabha, the headman of Jornagra village; local guides Durga Rabha, Gala Basumatary and Kharam Rabha; and other members of the Jornagra, Bandarpara and Kaljani communities who gave invaluable help and support during data collection.

\section{Author contributions}

ST conducted the field study and collected quantitative and qualitative data, and wrote the first draft of the article. AG drafted the interview schedule and prepared the final version of the article.

\section{References}

Аввот, J.I.O., Thomas, D.H.L., Gardner, A.A., Neba, S.E. \& Khen, M.W. (2001) Understanding the links between conservation and development in the Bamenda Highlands, Cameroon. World Development, 29, 1115-1136.

Anthwal, A., Gupta, N., Sharma, A., Anthwal, S. \& Kim, K.-H. (2010) Conserving biodiversity through traditional beliefs in sacred groves in Uttarakhand Himalaya, India. Resources, Conservation and Recycling, 54, 962-971.

Badola, R. (1998) Attitudes of local people towards conservation and alternatives to forest resources: a case study from the lower Himalayas. Biodiversity and Conservation, 7, 1245-1259.

BAIshy A, D. (2001) Elements of science and technology in the traditional lore of northeast India with particular reference to Assam: an exploratory study. $\mathrm{PhD}$ thesis. Tezpur University, Assam, India.

BajRacharya, S.B., Furley, P.A. \& NeWton, A.C. (2006) Impacts of community-based conservation on local communities in the Annapurna Conservation Area, Nepal. Biodiversity and Conservation, 15, 2765-2786.

Barre, R.Y., Grant, M. \& Draper, D. (2009) The role of taboos in conservation of sacred groves in Ghana's Tallensi-Nabdam district. Social \& Cultural Geography, 10, 25-39.

Berkes, F. (2004) Rethinking community-based conservation. Conservation Biology, 18, 621-630.

Berkes, F., Colding, J. \& Folke, C. (200o) Rediscovery of traditional ecological knowledge as adaptive management. Ecological Applications, 10, 1251-1262. 
Bernard, H.R. (2002) Research Methods in Anthropology: Qualitative and Quantitative Approaches. AltaMira Press, Lanham, USA.

Bhagwat, S.A., Kushalappa, C.G., Williams, P.H. \& Brown, N.D. (2005) The role of informal protected areas in maintaining biodiversity in the Western Ghats of India. Ecology and Society, 10, http://www.ecologyandsociety.org/volio/iss1/art8/.

Bhakat, R.K. \& Pandit, P.K. (2003) Role of a sacred grove in conservation of medicinal plants. Indian Forester, 129, 224-232.

Вово, K.S., А gномо, F.F.M. \& Ntumwel, B.C. (2014) Wildlife use and the role of taboos in the conservation of wildlife around the Nkwende Hills Forest Reserve, South-west Cameroon. Journal of Ethnobiology and Ethnomedicine, 11, 2-23.

Boraiah, K.T., Vasudeva, R., Bhagwat, S.A. \& Kushalappa, C.G. (2003) Do informally managed sacred groves have higher richness and regeneration of medicinal plants than state-managed reserve forests? Current Science, 84, 804-808.

BRAndon, K. (2000) People, parks, forests or fields: a realistic view of tropical forest conservation. Land Use Policy, 12, 137-144.

Byers, B.A., Cunliffe, R.N. \& Hudak, A.T. (2001) Linking the conservation of culture and nature: a case study of sacred forests in Zimbabwe. Human Ecology, 29, 187-218.

Chandran, M.D.S. \& Hughes, J.D. (200o) Sacred groves and conservation: the comparative history of traditional reserves in the Mediterranean area and in South India. Environment and History, 6 , 169-186.

Colding, J. \& Folke, C. (2001) Social taboos: "invisible" systems of local resource management and biological conservation. Ecological Applications, 11, 584-600.

Damania, R., Stringer, R., Karanth, K.U. \& Stith, B. (2003) The economics of protecting tiger populations: linking household behavior to poaching and prey depletion. Land Economics, 79, 198216.

Datta, S., Datta, J.M. \& Phukon, M.P. (1998) Chakrashila Wildlife Sanctuary: A Documentation of its Biodiversity. Assam Science, Technology and Environment Council, Guwahati, India.

Deb, D., Deuti, K. \& Malhotra, K.C. (1997) Sacred grove relics as bird refugia. Current Science, 73, 815-817.

Deb, D. \& Malhotra, K.C. (2001) Conservation ethos in local traditions: the West Bengal heritage. Society and Natural Resources, $14,711-724$.

DE Boer, W.F. \& BAquete, D.S. (1998) Natural resource use, crop damage and attitudes of rural people in the vicinity of the Maputo Elephant Reserve, Mozambique. Environmental Conservation, 25, 208-218.

Dollo, M., Gopi, G.V., Teegalapalli, K. \& Mazumdar, K. (2010) Conservation of the orange-bellied Himalayan squirrel Dremomys lokriah using a traditional knowledge system: a case study from Arunachal Pradesh, India. Gorat, 44, 573-576.

Ebua, V.B., Agwafo, T.E. \& Fonkwo, S.N. (2011) Attitude and perceptions as threats to wildlife conservation as Bakossi area, South West Cameroon. International Journal of Biodiversity and Conservation, 3, 631-636.

Fiallo, E.A. \& Jacobson, S.K. (1995) Local communities and protected areas: attitudes of rural residents towards conservation and Machalilla National Park, Ecuador. Environmental Conservation, 22, 241-249.

Ghimire, K.B. \& Pimbert, M.P. (1997) Social change and conservation: an overview of issues and concepts. In Social Change and Conservation (eds P.G. Krishna \& P.P. Michel), pp. 1-45. Earthscan, London, UK.

Gillingham, S. \& Lee, P.C. (1999) The impact of wildlife-related benefits on the conservation attitudes of local people around the Selous Game Reserve, Tanzania. Environmental Conservation, 26, 218-228.
Gupta, A. \& Guha, K. (2002) Tradition and conservation in northeastern India: an ethical analysis. Eubios Journal of Asian and International Bioethics, 12, 15-18.

Gupta, N., Kanagavel, A., Dandekar, P., Dahanukar, N., Sivakumar, K., Mathur, V.B. \& Raghavan, R. (2016) God's fishes: religion, culture and freshwater fish conservation in India. Oryx, 50, 244-249.

Hamilton, A., Cunningham, A., Byarugaba, D. \& Kayanja, F. (2000) Conservation in a region of political instability: Bwindi Impenetrable Forest, Uganda. Conservation Biology, 14, 1722-1725.

Heinen, J.T. (1993) Park-people relations in Koshi Tappu Wildlife Reserve, Nepal: a socio-economic analysis. Environmental Conservation, 20, 25-34.

Hill, C.M. (200o) Conflict of interest between people and baboons: crop raiding in Uganda. International Journal of Primatology, 21, 299-315.

HoAre, R.E. \& DU Toit, J.T. (1999) Coexistence between people and elephants in African savannas. Conservation Biology, 13, 633-639.

Jhala, Y.V. (1993) Damage to Sorghum crop by blackbuck. International Journal of Pest Management, 39, 23-27.

Jimoh, S.O., IкyaAgba, E.T., Alarape, A.A., Овiоha, E.E. \& Adeyemi, A.A. (2012) The role of traditional laws and taboos in wildlife conservation in the Oban Hill Sector of Cross River National Park (CRNP), Nigeria. Journal of Human Ecology, 39, 209-219.

Kalibo, H.W. \& Medley, K.E. (2007) Participatory resource mapping for adaptive collaborative management at Mt. Kasigau, Kenya. Landscape and Urban Planning, 82, 145-158.

Kaltenborn, B.P., Bjerke, T., Nyahongo, J.W. \& Williams, D.R. (2006) Animal preferences and acceptability of wildlife management actions around Serengeti National Park, Tanzania. Biodiversity and Conservation, 15, 4633-4649.

Karanth, K.K., Kramer, R.A., Qian, S.S. \& Christensen, Jr, N.L. (2008) Examining conservation attitudes, perspectives and challenges in India. Biological Conservation, 141, 2357-2367.

Khan, M.L., Khumbongmayum, A.D. \& Tripathi, R.S. (2008) The sacred groves and their significance in conserving biodiversity: an overview. International Journal of Ecology and Environmental Sciences, 34, 277-291.

Khiewtam, R.S. \& Ramakrishnan, P.S. (1989) Socio-cultural studies of the sacred groves at Cherrapunji and adjoining areas in North-Eastern India. Man in India, 69, 64-71.

Kinnaird, M.F., Sanderson, E.W., O’Brien, T.G., Wibisono, H.T. \& Woolmer, G. (2003) Deforestation trends in a tropical landscape and implications for endangered large mammals. Conservation Biology, 17, 245-257.

Kothari, A., Pathak, N. \& Vania, F. (2000) Where Communities Care: Community Based Wildlife and Ecosystem Management in South Asia. International Institute of Environment and Development, London, UK, and Kalpavriksh, Pune, India.

Likert, R. (1974) The method of constructing an attitude scale. In Scaling: A Sourcebook for Behavioral Scientists (ed. G.M. Maranell), pp. 233-243. Aldine Publishing Company, Chicago, USA.

Lindenmayer, D.B. \& Franklin, J.F. (2003) Conserving Forest Biodiversity: A Comprehensive Multi-scaled Approach. Island Press, Washington, DC, USA.

Lingard, M., Raharison, N., Rabakonandrianina, E., Rakotoarisoa, J.A. \& Elmevist, T. (2003) The role of local taboos in conservation and management of species: the radiated tortoise in southern Madagascar. Conservation and Society, 1, 223-246.

Martin, E., Talukdar, B.K. \& Vigne, L. (2009) Rhino poaching in Assam: challenges and opportunities. Pachyderm, 46, 25-34.

McNeely, J.A. (1995) Partnerships for conservation: an introduction. In Expanding Partnerships in Conservation (ed. J.A. McNeely), pp. 1-10. Island Press, Washington, DC, USA. 
McNeely, J.A. \& Miller, K.R. (1994) National Park Conservation and Development. Smithsonian Institution Press, Washington, DC USA.

Menta, J.N. \& Heinen, J.T. (2001) Does community-based conservation shape favorable attitudes among locals? An empirical study from Nepal. Environmental Management, 28, 165-177.

Meyer-Rochow, V.B. (2009) Food taboos: their origins and purposes. Journal of Ethnobiology and Ethnomedicine, 5, 1-10.

Nagendra, H., Rocchini, D. \& Ghate, R. (2010) Beyond parks as monoliths: spatially differentiating park-people relationships in the Tadoba Andhari Tiger Reserve in India. Biological Conservation, 143, 2900-2908.

Naughton-Treves, L., Holland, M.B. \& Brandon, K. (2005) The role of protected areas in conserving biodiversity and sustaining local livelihoods. Annual Review of Environment and Resources, 30, 219-252.

NGara, R. \& MAngizvo, R.V. (2013) Indigenous knowledge systems and the conservation of natural resources in the Shangwe community in Gokwe district, Zimbabwe. International Journal of Asian Social Science, 3, 20-28.

Nyhus, P.J., Tilson, R. \& Sumianto (200o) Crop-raiding elephants and conservation implications at Way Kambas National Park, Sumatra, Indonesia. Oryx, 34, 262-274.

OGRA, M. (2009) Attitudes toward resolution of human-wildlife conflict among forest-dependent agriculturalists near Rajaji National Park, India. Human Ecology, 37, 161-177.

Ormsiy, A. (2013) Analysis of local attitudes toward the sacred groves of Meghalaya and Karnataka, India. Conservation and Society, 11, 187-197.

Ormsby, A. \& Bhagwat, S.A. (2010) Sacred forests of India: a strong tradition of community-based natural resource management. Environmental Conservation, 37, 320-326.

Osmond, P. (1994) Wildlife-human conflicts in Kenya: integrating wildlife conservation with human needs in Masai Mara region. $\mathrm{PhD}$ thesis. McGill University, Montreal, Canada.

PATNAIK, R. (2007) Ecology of food taboos and fishing technology: a complex system of resource partitioning among Jalari of north coastal Andhra Pradesh. Anthropologist, 9, 125-131.

Paul, A.K. \& Narzary, B. (2010) Let the World Know about Bodoland. Good Book Distributors Publishers, Kolkata, India.

Peterson, M.N., Peterson, M.J., Peterson, T.R. \& LiU, J. (2007) A household perspective for biodiversity conservation. The Journal of Wildlife Management, 71, 1243-1248.

Rangarajan, M. (2005) Fire in the forest. Economic and Political Weekly, 40, 4888-489o.

SAH, J.P. \& Heinen, J.T. (2001) Wetland resource use and conservation attitudes among indigenous and migrant peoples in Ghodaghodi Lake area, Nepal. Environmental Conservation, 28, 345-356.

Saj, T.L., Mather, C. \& Sicotte, P. (2006) Traditional taboos in biological conservation: the case of Colobus vellerosus at the Boabeng-Fiema Monkey Sanctuary, Central Ghana. Ethology and Ethnology, 45, 285-310.

SAJ, T.L., Sicotte, P. \& Paterson, J.D. (2001) The conflict between vervet monkeys and farmers at the forest edge in Entebbe, Uganda. African Journal of Ecology, 39, 195-199.
Sarker, A.H.M.R. \& RøSKaft, E. (2011) Human attitudes towards the conservation of protected areas: a case study from four protected areas in Bangladesh. Oryx, 45, 391-40o.

SASAKI, K., SASAKI, Y. \& Fox, S.F. (2010) Endangered traditional beliefs in Japan: influences on snake conservation. Herpetological Conservation and Biology, 5, 474-485.

Selvan, K.M., Veeraswami, G.G., Habib, B. \& Lyngdoh, S. (2013) Losing threatened and rare wildlife to hunting in Ziro Valley, Arunachal Pradesh, India. Current Science, 104, 1492-1495.

Shibia, M.G. (2010) Determinants of attitudes and perceptions on resource use and management of Marsabit National Reserve, Kenya. Journal of Human Ecology, 30, 55-62.

SingH, L.J., SingH, B. \& GuPt A, A. (2003) Environmental ethics in the culture of Meeteis from north-east India. In Asian Bioethics in the 21st Century (eds S.Y. Song, Y.M. Koo \& D.R.J. Macer), pp. 320-326. Eubios Ethics Institute, Tsukuba, Japan.

Soto, B., Munthali, S.M. \& Breen, C. (2001) Perceptions of the forestry and wildlife policy by the local communities living in the Maputo Elephant Reserve, Mozambique. Biodiversity and Conservation, 10, 1723-1738.

Studsrød, J.E. \& Wegge, P. (1995) Park-people relationships: the case of damage caused by park animals around the Royal Bardia National Park, Nepal. Environmental Conservation, 22, 133-142.

Talukdar, S. \& Gupta, A. (2014) Medicinal plants used by the Bodo community of Chakrashila Wildlife Sanctuary, Assam, India. Indian Journal of Applied Research, 4, 43-46.

Torri, M.C. (2010) Power, structure, gender relations and community-based conservation: the case study of the Sariska region, Rajasthan, India. Journal of International Women's Studies, 11, 1-18.

Udaya Sekhar, N. (1998) Crop and livestock depredation caused by wild animals in protected areas: the case of Sariska Tiger Reserve, Rajasthan, India. Environmental Conservation, 25, 160-171.

UDAYA SEKHAR, N. (2003) Local people's attitudes towards conservation and wildlife tourism around Sariska Tiger Reserve, India. Journal of Environmental Management, 69, 339-347.

Velho, N. \& Laurance, W.F. (2013) Hunting practices of an Indo-Tibetan Buddhist tribe in Arunachal Pradesh, north-east India. Oryx, 47, 389-392.

Walpole, M.J. \& Goodwin, H.J. (2001) Local attitudes towards conservation and tourism around Komodo National Park, Indonesia. Environmental Conservation, 28, 160-166.

Winter, S.J., Esler, K.J. \& Kidd, M. (2005) An index to measure the conservation attitudes of landowners towards Overberg Coastal Renosterveld, a critically endangered vegetation type in the Cape Floral Kingdom, South Africa. Biological Conservation, 126, 383-394.

\section{Biographical sketches}

SIMI TALUKDAR's research is focused on community-based conservation, resource utilization patterns of indigenous communities, and their attitude towards forest and wildlife conservation, in western Assam, India. Авнгк Gupta's research interests include environmental ethics and history, and nature-culture interactions. 